Jurnal Health Sains: p-ISSN: 2723-4339 e-ISSN: 2548-1398

Vol. 2, No. 6, Juni 2021

\title{
PERBANDINGAN LATIHAN OTOT INTI DENGAN LATIHAN PERGELANGAN KAKI DALAM MENINGKATKAN KELINCAHAN PEMAIN SEPAK BOLA
}

Dimas Agusta Noron, I Made Jawi, Wahyuddin, Putu Astawa, I Nyoman Adiputra, Susy Purnawati

Universitas Udayana, Denpasar dan Universitas Esa Unggul, Jakarta, Indonesia

Email: dimasnoron23@gmail.com, made_jawi@yahoo.co.id, wahyuddin@esaunggul.ac.id, putu_astawa@yahoo.com, nadip2003@yahoo.com, s_purnawati@yahoo.com

\begin{tabular}{l}
\hline ARTIKEL INFO \\
\hline Diterima: 5 Juni 2021 \\
Direvisi: 15 Juni 2021 \\
Disetujui: 25 Juni 2021 \\
\hline Keywords: \\
soccer; core muscle stability \\
exercise; ankle stability \\
exercise; dribbling agility
\end{tabular}

\begin{abstract}
Sport is a needs for human being, sport that early introduced in a young people giving a good effect for physical condition, psychology, and social. Along the growth and development of young soccer player, makes some transformation to their physical condition and to have an impact to their body proportional and decreasing of coordination and agility. To support dribbling skill, a soccer player need to have a good agility. The stability of your core muscle and your ankle affected the agility. The objective of this research is to explain the effect of core muscle stability exercise and ankle stability exercise for dribbling agility, and to compare both of exercises for dribbling agility on soccer player age 14-17 years old. This research used quasi-experimental methods. Subject divided into 2 group, that is Group 1 with core stability exercise intervention and Group 2 with ankle stability exercise intervention. The research will be done in 6 weeks, and 3 times a week. The dribbling agility measurement in this study used Dribbling Agility Test (DAT). From 14 subject, was obtained the difference average of dribbling agility value from the group with core muscle stability exercise was $1.8 \pm 1.3$ second ( $p$-value $=0.010$, $p<0.05)$, and the difference average of dribbling agility value from the group with ankle stability exercise was $2.29 \pm 1.37$ second ( $p$-value $=0.005, p<0.5)$. There is no difference between the group in increasing dribbling agility with $p$ value $=0.477(p>0.05)$. Both exercises shown improvement in each group in increasing dribbling agility with no difference between the group.
\end{abstract}

\section{ABSTRAK}

Olahraga merupakan suatu kebutuhan bagi manusia, Pengenalan dan pelatihan keolahragaan yang dimulai sejak usia dini memberikan pengalaman yang dapat menjadi kebiasaan baik bagi anak-anak, baik dari perkembangan kondisi fisik, psikologi, dan sosial. Seiring dengan pertumbuhan dan perkembangan pada pemain sepak bola usia muda, mengakibatkan adanya perubahan pada kondisi fisik, proporsi tubuh, dan penurunan koordinasi dan

\begin{tabular}{ll}
\hline How to cite: & Noron, Dimas Agusta. et, al. (2021) Perbandingan Latihan Otot Inti dengan Latihan Pergelangan \\
& Kaki dalam Meningkatkan Kelincahan Pemain Sepak Bola. Jurnal Health Sains 2(6). \\
& https://doi.org/10.46799/jhs.v2i6.186 \\
E-ISSN: & $2723-6927$ \\
Published by: & Ridwan Institute
\end{tabular}


Perbandingan Latihan Otot Inti dengan Latihan Pergelangan Kaki dalam Meningkatkan Kelincahan Pemain Sepak Bola

Kata Kunci:

sepak bola; latihan stabilitas otot inti; latihan stabilitas pergelangan kaki; kelincahan menggiring bola kelincahan. Untuk mendukung kemampuan menggiring bola, seorang pemain sepak bola harus memiliki kelincahan yang baik. Stabilitas otot inti dan pergelangan kaki berpengaruh terhadap kelincahan gerak. Tujuan dari penelitian ini adalah untuk menjelaskan pengaruh latihan stabilitas otot inti dan latihan stabilitas pergelagan kaki terhadap kelincahan menggiring bola, dan membandingkan keduanya terhadap kelincahan menggiring bola pada pemain sepak bola usia 1417 tahun. Penelitian ini menggunakan metode kuasieksperimental. Subjek dibagi menjadi 2 kelompok, yaitu Kelompok 1 dengan latihan stabilitas otot inti dan Kelompok 2 dengan latihan stabilitas pergelangan kaki. Penelitian ini dilakukan selama 6 minggu, dan 3 kali seminggu. Pengukuran kelincahan menggiring bola menggunakan Dribbling Agility Test (DAT). Dari 14 subjek didapatkan selisih rata-rata kelincahan menggiring bola Kelompok 1 adalah $1,8 \pm 1,3$ detik $(\mathrm{p}=0,010)$, dan pada Kelompok 2 adalah $2,29 \pm 1,37$ detik $(\mathrm{p}=0,005)$. Tidak ada perbedaan perbandingan antara kedua kelompok terhadap peningkatan kelincahan menggiring bola dengan nilai $p=0,477$. Kedua latihan menunjukkan adanya peningkatan pada setiap kelompok, dengan tidak adanya perbedaan yang bermakna peningkatan kelincahan menggiring bola antara kedua kelompok.

\section{Pendahuluan}

Olahraga merupakan suatu kebutuhan bagi manusia, karena manusia adalah makhluk yang dinamis atau selalu bergerak. Manusia selalu bergerak dalam melakukan aktivitasnya, karena tiada kehidupan tanpa adanya gerakan. Ada beberapa komponen yang harus dimiliki untuk mencapai performa olahraga yang baik, diantaranya adalah kapasitas kardiovaskuler, kapasitas pulmonal, performa otot, fleksibilitas, kelincahan, dan psikologis. Pengenalan olahraga sejak usia dini dapat memberikan pengalaman yang baik bagi kondisi fisik, psikologis, dan sosial pada anak.

Sepak bola merupakan salah satu olahraga yang cukup terkenal di kalangan masyarakat. Pengenalan dunia olahraga sepak bola sejak dini kepada anak-anak diharapkan dapat memberikan pengaruh yang positif bagi regenerasi atlet sepak bola di Indonesia. Fase latihan sepakbola dibagi menjadi 4 fase, yaitu fase kegembiraan sepakbola (usia 6 - 9 tahun), fase pengembangan skill sepak bola (usia $10-13$ tahun), fase pengembangan permainan sepak bola (usia 14 - 17 tahun), dan fase penampilan (usia di atas 18 tahun). Fase usia $14-17$ tahun sering disebut sebagai usia pubertas. Di mana secara alami pemain mengalami era pertumbuhan pesat yang ke dua. Hal yang jelas tampak adalah tinggi badan pemain mengalami kenaikkan pesat. Meski demikian, secara alami pula pemain beranjak semakin dewasa. Ia makin memiliki konsep diri yang kuat. Kebutuhan akan pengembangan diri menjadi makin besar. Salah satu, konsekuensi yang terjadi adalah tubuh tidak proporsional dan koordinasi dan kelincahan menurun (Danurwindo, 2017).

Dalam dunia permainan sepak bola di Indonesia, terdapat beberapa kesulitan yang terjadi secara teknis yang berpengaruh terhadap performa dan prestasi pemain atau atlet sepak bola. Hal tersebut diantaranya adalah kesulitan dalam menggiring bola, kesulitan dalam mengontrol bola, dan 
Dimas Agusta Noron, I Made Jawi, Wahyuddin, Putu Astawa, I Nyoman Adiputra, Susy Purnawati

kesulitan dalam menerobos pertahanan lawan. Beberapa komponen yang kemudian berkontribusi dalam performa atlet dapat disebutkan sebagai berikut yaitu kelincahan dan daya tahan pemain atau atlet sepak bola dalam kemampuannya untuk menggiring bola (Aldiansyah, 2014). Selama permainan sepak bola berlangsung, pemain melakukan gerakan dengan aktivitas rendah seperti berjalan, berlari kecil atau melakukan gerakan yang berhubungan dengan aktivitas tinggi seperti berlari, melompat, dan gerakan dengan perubahan arah (Rouissi et al., 2016).

Otot inti berfungsi untuk menstabilisasi thorakal dan pelvis selama terjadinya gerakan dinamis. Kontraksi otot inti secara statis secara fungsional memiliki kemampuan untuk mempertahankan kesejajaran (alignment) dari susunan tulang dalam menahan gaya agar tidak terjadinya perubahan (Sighamoney et al., 2018). Kekuatan otot-otot inti mempengaruhi peningkatan performa daya ledak dan kelincahan gerak (Dinc et al., 2019) Kekuatan otot inti memiliki dampak positif pada kelincahan gerak (Khare et al., 2017).

Latihan yang diberikan kepada sendi pergelangan kaki secara bersamaan akan meningkatkan stabilitas pada sendi pergelangan kaki itu sendiri, sehingga semakin meningkatnya stabilitas sendi pergelangan kaki akan meningkatkan kelincahan gerak pada seorang pemain atau atlet olahraga. Kontrol postural berhubungan dengan keseimbangan. Terdapat hubungan positif antara kelincahan dengan keseimbangan (Stirling, 2018).

Berdasarkan permasalahan diatas maka peneliti melakukan penelitian membandingkan mana yang lebih baik antara latihan stabilitas otot inti dengan latihan stabilitas sendi pergelangan kaki dalam meningkatkan kelincahan menggiring bola.

Tujuan penelitian ini adalah untuk Perbandingan Latihan Stabilitas Otot Inti Dengan Latihan Stabilitas Sendi Pergelangan Kaki Dalam Meningkatkan Kelincahan
Menggiring Bola Pada Pemain Sepak Bola Usia 14-17 Tahun.

\section{Metode Penelitian}

Metode penelitian yang digunakan pada penelitian ini adalah kuasieksperimental. Subjek penelitian adalah pemain sepak bola usia 14-17 tahun di Sekolah Sepak Bola di Cibubur. Teknik pengambilan sampel menggunakan purposive sampling dengan kriteria inklusi dan eksklusi sebagai acuan pengambilan sampel. Setelah jumlah subjek terpenuhi kemudian subjek dibagi menjadi 2 kelompok dengan menggunakan random alokasi dimana ditiap kelompok terdapat 7 subjek penelitian.

Prosedur penelitian dimulai dengan melakukan seleksi kepada anggota aktif Sekolah Sepak Bola di Cibubur sebagai subjek penelitian menggunakan angket, membagi subjek yang lolos seleksi ke dalam 2 (dua) kelompok berbeda yang kemudian dilakukan pre test kemampuan kelincahan menggiring bola, memberikan intervensi berupa pemberian latihan stabilitas otot inti pada Kelompok Perlakuan 1 dan memberikan latihan stabilitas sendi pergelangan kaki pada Kelompok Perlakuan 2. Latihan stabilitas otot inti diberikan selama 35 menit dan latihan stabilitas sendi pergelangan kaki di berikan selama 30 menit dengan penjadwalan $3 x$ seminggu pada hari yang sama dengan pemberian latihan pengembangan kemampuan selama 6 minggu, melakukan evaluasi kemampuan kelincahan menggiring bola sebagai post test pada ke dua kelompok, menganalisis selisih pre test dan post test kemampuan kelincahan menggiring bola pada masing-masing kelompok dengan menggunakan program komputer SPSS versi 16 , menganalisis perbandingan nilai ratarinstrumenata masing-masing post test kemampuan kelincahan menggiring bola dari ke dua kelompok dengan menggunakan program komputer SPSS versi 16, menyusun analisis dalam bentuk laporan dan melakukan publikasi hasil. 
Perbandingan Latihan Otot Inti dengan Latihan Pergelangan Kaki dalam Meningkatkan Kelincahan Pemain Sepak Bola

Untuk tahap evaluasi alat ukur yang digunakan pada penelitian ini adalah Dribbling Agility Test (DAT) untuk mengukur kelincahan menggiring bola pada pemain sepak bola. Tahapan tes yang harus dilakukan adalah diawali dengan subjek berdiri di area kotak kecil di tengah area kotak besar dengan panjang sisi 1 meter, kemudian subjek berlari sambil menggiring bola ke arah patokan yang telah ditentukan oleh peneliti, subjek kembali ke area kotak kecil di tengah area kotak besar dengan panjang sisi 7 meter, subjek kembali berlari sambil menggiring bola ke arah patokan yang telah ditentukan olah peneliti, subjek mengulang gerakan yang sama sebanyak 8 (delapan) kali, penghitungan waktu tempuh diberhentikan setelah subjek menyelesaikan siklus terakhir, ditandai dengan subjek kembali ke area kotak kecil dengan menggiring bola.

\section{Hasil dan Pembahasan}

\section{A. Hasil Penelitian}

Karakteristik berupa kondisi fisik subjek penelitian meliputi usia, indeks massa tubuh, dan perbandingan rata-rata nilai kelincahan menggiring bola sebelum dan setelah diberikan intervensi. Deskripsi karakteristik subjek penelitian tertera pada Tabel 1.

\section{Tabel 1}

\begin{tabular}{cccc}
\multicolumn{4}{c}{ Karakteristik Subjek Penelitian } \\
\hline $\begin{array}{c}\text { Karakteristik } \\
\text { Subjek }\end{array}$ & $\begin{array}{c}\text { Kelompok } \\
\text { Perlakuan } \\
1 \\
\left(\begin{array}{c}1 \\
(\text { mean } \pm S D)\end{array}\right.\end{array}$ & $\begin{array}{c}\text { Kelompok } \\
\text { Perlakuan 2 } \\
(\text { mean } \pm S D)\end{array}$ & $\begin{array}{c}p \text { - } \\
\text { value }\end{array}$ \\
\hline Usia (tahun) & $16,00 \pm 1,00$ & $16,29 \pm 0,75$ & 0,558 \\
\hline $\begin{array}{c}\text { Indeks Massa } \\
\text { Tubuh }\left(\text { Kg } / \mathrm{m}^{2}\right)\end{array}$ & $20,89 \pm 0,98$ & $21,15 \pm 1,98$ & 0,764 \\
\hline $\begin{array}{c}\text { Kelincahan } \\
\text { Mengiring Bola } \\
\text { (detik) }\end{array}$ & $37,55 \pm 0,73$ & $38,69 \pm 1,99$ & 0,182 \\
\hline $\begin{array}{c}\text { Statistik } \\
\text { Deskriptif }\end{array}$ & & & \\
\hline
\end{tabular}

Dari hasil analisis deskriptif data di atas menunjukan bahwa nilai probabilitas dari jenis karakteristik sampel menunjukkan angka $>0,05$, sehingga dapat disimpulkan bahwa tidak ada perbedaan yang bermakna antara tiap kelompok sebelum diberikan perlakuan.

Untuk menguji normalitas distribusi data digunakan uji Shapiro Wilk test. Sedangkan untuk mengetahui homogenitas varian data subjek penelitian digunakan Levene's test. Hasil uji normalitas distribusi data nilai kelincahan menggiring bola dapat dilihat pada Tabel 5.2 dan hasil uji homogenitas varian data nilai kelincahan menggiring bola dapat di lihat pada Tabel 2.

\section{Tabel 2}

Uji Normalitas dan Uji Homogenitas

\begin{tabular}{|c|c|c|c|}
\hline \multirow[b]{2}{*}{$\begin{array}{c}\text { Kelincahan } \\
\text { Menggiring } \\
\text { Bola }\end{array}$} & \multicolumn{2}{|c|}{ Uji Normalitas $^{\mathrm{a}}$} & \multirow[b]{2}{*}{$\begin{array}{c}\mathrm{Uji} \\
\text { Homogenitas }\end{array}$} \\
\hline & $\begin{array}{c}\text { Kelompok } \\
\text { Perlakuan } \\
\text { 1fvg }\end{array}$ & $\begin{array}{l}\text { Kelompok } \\
\text { Perlakuan } 2\end{array}$ & \\
\hline Pre-test & 0,272 & 0,901 & 0,199 \\
\hline Post-test & 0,270 & 0,908 & 0,879 \\
\hline Difference & & & 0,336 \\
\hline \multicolumn{4}{|l|}{$\begin{array}{l}{ }^{a} \text { Saphiro } \\
\text { Wilk test }\end{array}$} \\
\hline${ }^{b}$ Levene's test & & & \\
\hline
\end{tabular}

Hasil uji normalitas pada Kelompok Perlakuan 1 dan Kelompok Perlakuan 2, nilai $\mathrm{p}$ kelincahan menggiring bola yang diukur dengan DAT pada pre test dan post test adalah $>0,05$ dengan kesimpulan distribusi data normal. Hasil uji homogenitas data didapatkan nilai $\mathrm{p}>0,05$ maka dapat disimpulkan bahwa data bersifat homogen. Maka untuk membuktikan Hipotesis 1 dan Hipotesis 2 digunakan paired-samples $t$ test, dan untuk membuktikan Hipotesis 3 digunakan independent-samples t test.

\section{Tabel 3}

Hasil Uji Paired Sample t Test

\begin{tabular}{|c|c|c|c|c|}
\hline \multirow{2}{*}{$\begin{array}{c}\text { Data } \\
\text { Kelincahan } \\
\text { Menggiring } \\
\text { Bola }\end{array}$} & \multicolumn{2}{|c|}{$\begin{array}{c}\text { Kelompok Perlakuan } \\
1 \\
\end{array}$} & \multicolumn{2}{|c|}{ Kelompok Perlakuan 2} \\
\hline & mean $\pm S D$ & $p$-value & mean $\pm S D$ & $p$-value \\
\hline Pre-test (detik) & $\begin{array}{c}37,55 \pm \\
0,73\end{array}$ & & $\begin{array}{c}38,69 \pm \\
1,99\end{array}$ & \\
\hline $\begin{array}{c}\text { Post-test } \\
\text { (detik) }\end{array}$ & $\begin{array}{c}35,75 \pm \\
1,24\end{array}$ & 0,010 & $\begin{array}{c}36,40 \pm \\
1,97\end{array}$ & 0,005 \\
\hline $\begin{array}{l}\text { Selisih rata-rata } \\
\text { (detik) }\end{array}$ & $\begin{array}{c}1,80 \pm \\
1,30\end{array}$ & & $2,29 \pm 1,37$ & \\
\hline $\begin{array}{c}\text { Paired-sample } \\
\text { t test }\end{array}$ & & & & \\
\hline
\end{tabular}


Dimas Agusta Noron, I Made Jawi, Wahyuddin, Putu Astawa, I Nyoman Adiputra, Susy Purnawati

Pada tabel 3, menunjukkan penurunan rata-rata kelincahan menggiring bola pada kedua kelompok yang diukur menggunakan DAT. Rata-rata waktu pada Kelompok Perlakuan 1 adalah 37,55 \pm 0,73 detik dan turun ke 35,75 $\pm 1,24$ detik dengan selisih rata-rata sebesar 1,80 \pm 1,30 detik. Rata-rata waktu pada Kelompok Perlakuan 2 adalah 38,69 \pm 1,99 detik dan turun ke 36,40 $\pm 1,97$ detik dengan selisih rata-rata sebesar 2,29 \pm 1,37 detik.

\section{Tabel 4}

\begin{tabular}{|c|c|c|c|}
\hline $\begin{array}{c}\text { Data } \\
\text { Kelincahan } \\
\text { Menggiring } \\
\text { Bola }\end{array}$ & $\begin{array}{c}\text { Kelompok } \\
\text { Perlakuan } 1 \\
(\text { mean } \pm S D)\end{array}$ & $\begin{array}{l}\text { Kelompok } \\
\text { Perlakuan } 2 \\
(\text { mean } \pm S D)\end{array}$ & $\begin{array}{c}p- \\
\text { value }\end{array}$ \\
\hline Post-test (detik) & $\begin{array}{c}35,75 \pm \\
1,24\end{array}$ & $\begin{array}{c}36,40 \pm \\
1,97\end{array}$ & 0,477 \\
\hline $\begin{array}{l}\text { Independent- } \\
\text { sample t test }\end{array}$ & & & \\
\hline
\end{tabular}

Dengan menggunakan uji tersebut didapatkan nilai probabilitas adalah 0,477 $(p>0,05)$. Hasil ini mengindikasikan bahwa tidak ada perbedaan yang signifikan peningkatan kelincahan menggiring bola antara Kelompok Perlakuan 1 dan Kelompok Perlakuan 2.

\section{B. Pembahasan}

Pada penelitian ini, efek dari latihan stabilitas otot inti dan latihan stabilitas sendi pergelangan kaki selama 8 minggu terhadap peningkatan menggiring bola telah terbukti. Dari evaluasi kelincahan menggiring bola dengen DAT, data menunjukkan penurunan rata-rata waktu, dimana dapat diartikan bahwa terdapat peningkatan kelincahan menggiring bola pada pemain sepak bola usia 14-17 tahun dengan latihan stabilitas otot inti dan latihan stabilitas sendi pergelangan kaki, hasil ini memberikan dampak positif bagi tim dan individu dalam meraih performa terbaik dalam berkompetisi.

Stabilitas postural merupakan hal yang krusial dalam menjaga keseimbangan tubuh selama lokomosi, berdiri, dan aktivitas lain yang membutuhkan derajat stabilitas yang lebih tinggi. Kelincahan dapat didefinisikan sebagai kemampuan untuk mengontrol dan menjaga posisi tubuh yang tepat ketika melakukan perubahan arah gerak yang cepat didalam suatu rangkaian gerakan, kontrol postural memiliki peran yang signifikan dalam banyak olahraga, dan kemampuan dalam menjaga kontrol postural dapat diidentikkan dengan kesuksesan dalam performa (Cengizhan, 2019) Latihan stabilitas otot inti menggunakan beban tubuh dapat meningkatkan kekuatan dari otot inti dan kontrol postural. Peningkatan kelincahan menggiring bola dengan kontrol postur yang baik dan kemudian dengan efektivitas dan efisiensi gerakan anggota gerak bawah tidak akan terganggu oleh gerakan dari badan dan bagian tubuh lain.

Dalam upaya untuk mencapai performa yang optimal pada pelaku olahraga amatir dan profesional, penting bagi tubuh untuk memiliki kekuatan dan durabilitas yang cukup. Stabilitas otot inti dan keseimbangan adalah hal yang penting bagi hampir seluruh olahraga dan aktivitas. Pelatihan otot inti berfokus pada peningkatan kekuatan dan daya dari otototot lokal dan global dimana bekerja secara bersamaan dalam menjaga stabilitas tulang belakang. Ketidakcukupan kekuatan otot inti dalam menjaga stabilitas pinggul dan badan kita dapat menurunkan kontrol titik tengah gravitasi tubuh (Dinc et al., 2019). Latihan otot inti dapat meningkatkan kecepatan dan kelincahan pada pemain sepak bola (Afyon et al., 2017). Otot-otot global (lebih luar) meliputi rectus abdominis, oblique, latissimus, dan otot-otot erektor tulang belakang kemudian grup otot-otot lokal (lebih dalam) meliputi transversus abdominis, multifidus, dan otot-otot dasar 
Perbandingan Latihan Otot Inti dengan Latihan Pergelangan Kaki dalam Meningkatkan Kelincahan Pemain Sepak Bola

panggul (Sekendiz et al., 2010). Kekuatan otot, fleksibilitas, daya tahan, koordinasi, keseimbangan, dan efisiensi gerak adalah komponen yang esensial dan merupakan satu kesatuan dari performa untuk mencapai gerakan fungsional dalam kemampuan yang berhubungan dengan olahraga (Gonzalez-Rodriguez et al., 2014).

Telah ditemukan studi yang berhubungan dengan latihan otot inti dalam sepak bola. Menurut (GonzalezRodriguez et al., 2014) melaporkan bahwa latihan keseimbangan otot inti dengan 11 gerakan selama 4 minggu dan 5 hari dalam seminggu memberikan peningkatan yang signifikan terhadap keseimbangan statis dan dinamis pada pemain sepak bola usia muda. Menurut (Granacher et al., 2014) menyatakan bahwa terdapat peningkatan yang signifikan pada perbandingan nilai keseimbangan 2 kelompok yang berbeda (kelompok dengan permukaan stabil dan kelompok dengan permukaan tidak stabil) ketika diterapkan program latihan otot inti selama 6 minggu pada 23 pemain sepak bola. Menurut (Afyon et al., 2017) menyatakan bahwa terdapat peningkatan yang signifikan terhadap kelincahan dan kecepatan ketika diterapkan program latihan otot inti selama 8 minggu dan 4 hari dalam seminggu didalam program latihan reguler pemain sepak bola.

Latihan stabilitas sendi pergelangan kaki dengan bertelanjang kaki memiliki hubungan dengan peningkatan kelincahan gerak dan stabilitas dari sendi pergelangan kaki (de Villiers \& Venter, 2014). Pemain sepak bola dengan stabilitas sendi pergelangan kaki yang baik akan diikuti juga dengan peningkatan kelincahan gerak yang baik. Efek dari latihan stabilitas sendi pergelangan kaki dalam aktivitas fungsional diantaranya adalah memiliki jarak langkahan yang lebih pendek, peningkatan frekuensi langkahan, penurunan kontak kaki terhadap permukaan, peningkatan stabilitas otot, dan menstimulasi propioseptif sendi pergelangan kaki. Peningkatan kelincahan menggiring bola and stabilitas sendi pergelangan kaki ada hubungannya dengan bagaimana stabilitas sendi pergelangan kaki menjaga keseimbangan tubuh, hal tersebut dapat menciptakan gerakan yang lebih efektif dan efisien.

Didalam sepak bola, pemain harus bisa melakukan lompatan dan gerakan yang bervariasi yang berhubungan dengan teknik yang dibutuhkan dalam mencapai performa tertinggi. Dalam peningkatan kelincahan gerak, perubahan arah gerak dan transisi harus dikuasai pada kecepatan tinggi, biasanya dengan langkahan yang lebih pendek (Goodman \& Brette, 2008). Menurut (de Villiers \& Venter, 2014) menyatakan bahwa studi yang mereka lakukan adalah studi pertama yang membandingkan efek program pengkondisian olahraga spesifik dengan bertelanjang kaki terhadap kecepatan, kelincahan dan stabilitas pergelangan kaki pada atlet dengan program latihan spesifik netball dengan bertelanjang kaki selama 8 minggu yang secara signifikan meningkatkan kelincahan kepada para pemain netball.

Latihan stabilitas otot inti dan latihan stabilitas sendi pergelangan kaki berhubungan dengan peningkatan kelincahan menggiring bola. Kedua latihan berdampak pada peningkatan keseimbangan tubuh dan gerakan anggota gerak bawah. Faktor yang mempengaruhi kelincahan salah satunya adalah aspek fisik di mana di dalamnya terdapat kualitas kekuatan otot kaki dan kekuatan dari otot inti (Young, 2011). Pada dasarnya ke dua latihan yang di bandingkan dalam penelitian ini secara bersama-sama membangun kelincahan. 
Dimas Agusta Noron, I Made Jawi, Wahyuddin, Putu Astawa, I Nyoman Adiputra, Susy Purnawati

Hasil uji dari post test kedua kelompok menunjukkan tidak adanya perbedaan antar kelompok dalam peningkatan kelincahan menggiring bola. Dalam upaya untuk mencapai performa yang optimal pada olahraga amatir maupun profesional, tubuh membutuhkan kekuatan dan durabilitas yang cukup.

\section{Kesimpulan}

Berdasarkan.hasil dari pencarian artikel yang didapatkan oleh peneliti maka dapat disimpulkan bahwa latihan stabilitas otot inti dapat meningkatkan kelincahan menggiring bola pada pemain sepak bola usia 14-17 tahun. Latihan stabilitas sendi pergelanagan kaki dapat meningkatkan kelincahan menggiring bola pada pemain sepak bola usia 14-17 tahun. Tidak bisa dibuktikan adanya perbedaan antara latihan stabilitas otot inti dengan latihan stabilitas sendi pergelangan kaki terhadap kelincahan menggiring bola pada pemain sepak bola usia 14 - 17 tahun

\section{BIBLIOGRAFI}

Afyon, Y. A., Mulazimoglu, O., \& Boyaci, A. (2017). The effects of core trainings on speed and agility skills of soccer players. International Journal of Sports Science, 7(6), 239-244. Google Scholar

Aldiansyah, A. G. (2014). Sistem Pendukung Keputusan Pemilihan Telepon Seluler Menggunakan Metode Analytic Network Process (ANP). Universitas Dian Nuswantoro Semarang. Google Scholar

Cengizhan, S. (2019). Sınıf Öğretmenlerinin Özel Yetenekli Öğrenciler İçin Etkinlik Tasarlamada-Uygulamada Karşılaştıkları Güçlükler Ve Eğitime İlişkin Görüşleri. Anemon Muş Alparslan Üniversitesi Sosyal Bilimler Dergisi, 7(5), 27-36. Google Scholar

Danurwindo, P. (2017). G., \& Sidik, B.
Kurikulum Pembinaan Sepakbola Indonesia, 1-11. Google Scholar

de Villiers, J. E., \& Venter, R. E. (2014). Barefoot training improved ankle stability and agility in netball players. International Journal of Sports Science \& Coaching, 9(3), 485-495. Google Scholar

Dinc, E., Kuscu, M., Bilgin, B. A., \& Akan, O. B. (2019). Internet of Everything: A Unifying Framework Beyond Internet of Things. In Harnessing the Internet of Everything (IoE) for Accelerated Innovation Opportunities (pp. 1-30). IGI Global. Google Scholar

Gonzalez-Rodriguez, A., Mayoral, R., Agra, N., Valdecantos, M. P., Pardo, V., Miquilena-Colina, M. E., VargasCastrillón, J., Iacono, O. Lo, Corazzari, M., \& Fimia, G. M. (2014). Impaired autophagic flux is associated with increased endoplasmic reticulum stress during the development of NAFLD. Cell Death \& Disease, 5(4), e1179-e1179. Google Scholar

Goodman, D. F. M., \& Brette, R. (2008). Brian: a simulator for spiking neural networks in python. Frontiers in Neuroinformatics, 2, 5. Google Scholar

Granacher, U., Schellbach, J., Klein, K., Prieske, O., Baeyens, J.-P., \& Muehlbauer, T. (2014). Effects of core strength training using stable versus unstable surfaces on physical fitness in adolescents: a randomized controlled trial. BMC Sports Science, Medicine and Rehabilitation, 6(1), 1-11. Google Scholar

Khare, S., Lila, A. R., Patil, R., Phadke, M., Kerkar, P., Bandgar, T., \& Shah, N. S. (2017). Long-term cardiac (valvulopathy) safety of cabergoline in prolactinoma. Indian Journal of Endocrinology and Metabolism, 21(1), 154. Google Scholar

Rouissi, M., Chtara, M., Owen, A., Chaalali, 
Perbandingan Latihan Otot Inti dengan Latihan Pergelangan Kaki dalam Meningkatkan Kelincahan Pemain Sepak Bola

A., Chaouachi, A., Gabbett, T., \& Chamari, K. (2016). Effect of leg dominance on change of direction ability amongst young elite soccer players. Journal of Sports Sciences, 34(6), 542-548. Google Scholar

Sekendiz, B., Cug, M., \& Korkusuz, F. (2010). Effects of Swiss-ball core strength training on strength, endurance, flexibility, and balance in sedentary women. The Journal of Strength \& Conditioning Research, 24(11), 30323040. Google Scholar

Sighamoney, R., Kad, R., \& Yeole, U. L. (2018). Effect of core strengthening on dynamic balance and agility in badminton players. International Journal of Physical Education, Sports and Health, 5(1), 86-88. Google

Copyright holder:

Dimas Agusta Noron, I Made Jawi, Wahyuddin, Putu Astawa, I Nyoman Adiputra, Susy Purnawati (2021)

First publication right:

Jurnal Health Sains

This article is licensed under:

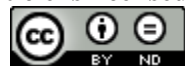

